\title{
ELEVATED BMI IS CONSIDERABLY ASSOCIATED WITH IDD RATHER THAN POLYMORPHIC VARIATIONS IN INTERLEUKIN-1 AND VITAMIN D RECEPTOR GENES: A CASE-CONTROL STUDY
}

\author{
POVIŠEN BMI ZNAČAJNO JE POVEZAN SA IDD-OM ZA RAZLIKU OD POLIMORFNIH \\ VARIJACIJA U INTERLEUKINU-1 I GENIMA RECEPTORA ZA VITAMIN D: \\ STUDIJA SLUČAJA SA KONTROLNIM ISPITANICIMA
}

\author{
Mazhar Salim Al Zoubi ${ }^{1}$, Osama Otoum², Mohammed Alsmadi ${ }^{3}$, Riyadh Muhaidat ${ }^{2}$, Ahmed Albdour ${ }^{3}$ \\ Ziyad Mohaidat ${ }^{4}$, Manal Issam Abu Alarjah'1, Raed M. Al-Zoubi ${ }^{5}$, Khalid M. Al-Batayneh² \\ ${ }^{1}$ Department of Basic Medical Sciences, Faculty of Medicine, Yarmouk University, Irbid 211-63, Jordan \\ ${ }^{2}$ Department of Biological Sciences, Faculty of Science, Yarmouk University, Irbid 211-63, Jordan \\ ${ }^{3}$ King Hussein Medical Centre, Royal Medical Services, Amman, Jordan \\ ${ }^{4}$ Faculty of Medicine, Jordan University of Science and Technology, Irbid, Jordan \\ ${ }^{5}$ Department of Chemistry, Jordan University of Science \& Technology, Irbid, 22110, Jordan
}

\begin{abstract}
Summary
Background: Intervertebral disc degeneration (IDD) is a musculoskeletal disorder and one of the major causes of low back pain leading to the disability with high economic repercussions worldwide. This study applied the candidategene approach to investigate the potential association of selected polymorphisms with IDD development in a Jordanian population.

Methods: MRI-diagnosed IDD patients $(\mathrm{N}=155)$ and asymptomatic individuals as a control group $(\mathrm{N}=55)$. Whole blood samples for four variants in three genes (rs 1800587 of IL-1 $\alpha$, rs 1143634 of IL-1 $\beta$ and rs 2228570 and rs 731236 of VDR) were genotyped by PCR-RFLP.

Results: There was no significant association between the studied polymorphisms or their allelic frequency and the occurrence of IDD. However, the cohort presented a significant reverse association between $r$ s $1143634 \mathrm{C}>\mathrm{T}$ of the IL-1 $\beta$ gene and the occurrence of IDD ( $p<0.0001)$. In addition, BMI showed a significant association with the IDD in the study population $(p<0.005)$. The current study was
\end{abstract}

\begin{abstract}
Kratak sadržaj
Uvod: Degeneracija intervertebralnog diska (IDD) je mišićno-koštani poremećaj i jedan od glavnih uzroka bolova u donjem delu leđa koji vodi do invaliditeta i ima velike ekonomske posledice širom sveta. $U$ ovom istraživanju korišćen je pristup određivanja gena kandidata kako bi se istražila potencijalna povezanost odabranih polimorfizama sa razvojem IDD-a u jordanskoj populaciji.

Metode: IDD pacijenti dijagnostikovani putem magnetne rezonantne tomografije (MRI) $(\mathrm{N}=155)$ i asimptomatski pojedinci kao kontrolna grupa $(N=55)$. Određen je genotip celokupnih uzoraka krvi za četiri varijante u tri gena (rs1800587 u IL-1 $\alpha$, rs 1143634 u IL-1 $\beta$ i rs2228570 i rs731236 u VDR) pomoću PCR-RFLP.

Rezultati: Nije bilo značajne povezanosti između proučavanih polimorfizama ili njihove učestalosti alela i pojave IDD-a. Međutim, kohorta je pokazala značajnu obrnutu povezanost između rs1143634 C > T koji pripada genu IL-1 $\beta$, i pojave IDD-a ( $<0,0001)$. Pored toga, BMI je pokazao značajnu povezanost sa IDD-om u ispitivanoj
\end{abstract}

Address for correspondence:

Dr Khalid Al-Batayneh

Department of Biological Sciences, Faculty of Science,

Yarmouk University, Irbid 211-63, Jordan

e-mail: albatynehk@yu.edu.jo

Dr Mazhar Al Zoubi

Department of Basic Medical Sciences, Faculty of Medicine,

Yarmouk University, Irbid 211-63, Jordan

e-mail:mszoubi@yu.edu.jo 
conceptualized based on the candidate-gene approach to investigate the role of inflammatory and metabolic genes, IL and VDR, respectively, in the occurrence of IDD.

Conclusions: While the data presented in this study showed that polymorphisms in these genes were not associated with IDD of the cohort investigated, elevated BMI, as a measure of obesity, is strongly associated with IDD. Investigating potential roles of other structural genes, such as col-IX and aggrecan (ACAN), in IDD and considering a GWAS to elucidate a genomically global look at the basis of IDD development would be of considerable impact on our understanding of IDD.

Keywords: IDD, VDR, IL-1 $\alpha$, IL-1 $\beta$, rs1800587, rs1143634, rs2228570, rs731236

\section{Introduction}

Intervertebral disc degeneration (IDD) is a chronic musculoskeletal disease characterized by a gradual loss of water and proteoglycans (PGs) from the nucleus pulposus with a high incidence of asymptomatic cases. Habitually, IDD is an unavoidable outcome of ageing; degeneration begins as early as the second decade of life. IDD affects about $84 \%$ of people worldwide with direct and indirect economic influence $(1,2)$. At the molecular level, IDDs are intimately associated with a sequence of biochemical and morphological changes in the discs that alter the biomechanical characters of the vertebrae $(3,4)$. The collagen network formed mostly of type I and type II collagen fibrils provides radially distributed tensile strength to the disc and anchors the tissue to the bone (5). As age increases, type II collagen production decreases, whereas type I collagen synthesis increases, leading to less compliant type I collagen. Consequently, the ratio and the relative distribution of type I and type II collagen in the outer annulus and a decrease in collagen cross-links make the annulus more susceptible to mechanical failure (6).

The complex nature of IDD development has been conceived by the interaction of unfavourable inheritance with many physical factors, such as occupation and workload, and other biological factors such as age, senescence, apoptosis, extracellular matrix composition with water content, and certain enzymatic activity levels. With all that taken together, disc impairment gradually increases to irreversible degeneration under certain sudden events or injuries (7). Nonetheless, genetic factors have been described as major contributors to IDD, accounting for 70\% of the variability in disc degeneration among identical twins (8). Recent studies confirmed IDD is associated with variable polymorphic gene families with IDD, especially those of extracellular matrix (9). Several structural, metabolic, inflammatory, and other genes have been found to play roles in developing IDD, and have been investigated in various populations, including Finnish, Japanese, and Chinese (10-12). populaciji ( $\mathrm{p}<0,005)$. Trenutno istraživanje je koncipirano na osnovu pristupa određivanja gena kandidata kako bi se istražila uloga upalnih (IL) i metaboličkih (VDR) gena pri pojavi IDD-a.

Zaključak: Dok su podaci predstavljeni u ovom istraživanju pokazali da polimorfizmi u ovim genima nisu povezani sa IDD-om kohorte koja je istraživana, povišen BMI, kao mera gojaznosti, snažno je povezan sa IDD-om. Ispitivanje potencijalnih uloga drugih strukturalnih gena, poput col-IX i agrekana (ACAN) u IDD-u, i razmatranje GWAS-a za razjašnjenje genomski globalnog pogleda na osnovu razvoja IDD-a, imalo bi značajan uticaj na naše razumevanje IDD-a.

Ključne reči: IDD, VDR, IL-1 $\alpha$, IL-1 $\beta$, rs1800587, rs1143634, rs2228570, rs731236

Allelic variation of the VDR gene has been found to be causative of musculoskeletal diseases, such as osteoarthritis (13) and osteoporosis (14), suggesting that VDR gene polymorphisms may underlie the development of IDD. For instance, rs 731236 and rs2228570 VDR and IL-1 gene polymorphisms have frequently been investigated for their potential role in IDD $(2,4)$. IL- $1 \alpha$ gene promoter holds a C > T polymorphism (rs 1800587) that is associated with the increased transcriptional activity of the gene when compared with the CC genotype (4). In addition, the rs 1143634 variant $(C>T)$ in exon 5 of the -1 gene has been found to be associated with an increase in IL-1 $\beta$ production levels (15).

The contribution of genetic factors to IDD development has been well studied in many populations such as Finnish, Spanish, Chinese, and Japanese, and, to our knowledge, none has so far been carried out in Jordan. Therefore, the current study aimed at examining selected polymorphisms rs 1800587 of IL$1 \alpha$, rs 1143634 of $I L-1 \beta$ and rs 2228570 and rs 731236 of VDR genes and evaluating their potential association with IDD in the Jordanian population.

\section{Materials and Methods}

\section{Patients and Sample collection}

Fresh whole blood samples for DNA extraction were collected from 210 individuals, 155 samples from IDD patients diagnosed by MRI at Prince Rashed Bin Al-Hasan Military Hospital, and the remaining 55 samples were collected from normal people (having no visual or apparent symptoms). Informed consent forms, as well as questionnaires, were taken after obtaining ethical approval from the Research Ethics Committee at Yarmouk University. Briefly, $4 \mathrm{~mL}$ of whole blood was collected in EDTA coated vacutainer tubes, and stored at $4{ }^{\circ} \mathrm{C}$ until use. 
DNA amplification and restriction fragment length polymorphism (PCR-RFLP)

The extraction of genomic DNA was carried out using the QIAamp ${ }^{\circledR}$ DNA Blood Mini Kit (QIAGEN, Germany) according to the manufacturer's instructions. Polymorphic variants were analyzed by polymerase chain reaction followed by restriction fragment length polymorphism (PCR-RFLP). A general PCR procedure included three steps: firstly, denaturation at $94{ }^{\circ} \mathrm{C}$ for $5 \mathrm{~min}$, followed by 35 cycles each cycle consists of denaturation at $94{ }^{\circ} \mathrm{C}$ for $30 \mathrm{sec}$, annealing for $30 \mathrm{sec}$ at $55^{\circ} \mathrm{C}$ and extension for $1 \mathrm{~min}$ at $68{ }^{\circ} \mathrm{C}$, and finally an extra extension step at $68^{\circ} \mathrm{C}$ for $5 \mathrm{~min}$. Table / summarizes the primer pairs used to amplify the target sequences of the selected genes. The studied genetic variations are summarized in Table II. A region of 193 bp spanning the rs 1800587 $(-899 \mathrm{C}>\mathrm{T})$ polymorphic site at the promoter region of IL-1 $\alpha$ gene was amplified and digested with a Ncol restriction enzyme ( $2 \mathrm{U}$ for $2 \mathrm{~h}$ at $37^{\circ} \mathrm{C}$ ) (New England Biolabs Inc., Beverly, MA) (16). Allele $\mathrm{C}$ has a restriction site giving two fragments of 174 and 19 bp, while allele $T$ has no recognition site. Furthermore, a region of 194 bp spanning the rs $1143634(+3954 \mathrm{C}$ $>$ T) polymorphic site at exon 5 of $I L-1 \beta$ gene was amplified and digested with a $\mathrm{Taq}^{\alpha} \mid$ restriction enzyme ( $2 \mathrm{U}$ for $2 \mathrm{~h}$ at $65^{\circ} \mathrm{C}$ ) (New England Biolabs Inc., Beverly, MA). Allele $\mathrm{C}$ has two restriction sites giving three fragments of 97,85 , and $12 \mathrm{bp}$, while allele $T$ has two recognition sites giving two fragments of 182 and $12 \mathrm{bp}$. PCR product of $265 \mathrm{bp}$ containing the single nucleotide polymorphism (SNP) rs 2228570 $(T>C)$ at the translation initiation codon of exon 2 of VDR gene was digested with a Fokl restriction enzyme ( $1 \mathrm{U}$ for $2 \mathrm{~h}$ at $37^{\circ} \mathrm{C}$ ) (New England Biolabs Inc., Beverly, MA) (16). Allele T has a restriction site giving two fragments of 197 and 68 bp, while allele $C$ has no recognition site. Similarly, the 747 bp amplicon spanning the synonymous polymorphism rs731236 (352 T > C) in exon 9 of the VDR gene (17) was cleaved with a $\operatorname{Taq}^{\alpha}$ I restriction enzyme $(2 \mathrm{U}$ for $2 \mathrm{~h}$ at $65^{\circ} \mathrm{C}$ ) (New England Biolabs Inc., Beverly, MA). Allele $T$ showed two fragments of 496 and 251 bp, while allele $\mathrm{C}$ generated an additional restriction site giving three fragments of 294, 251, and 201 bp. The resultant fragments from the restriction digestion reaction were detected and analyzed using 3\% agarose gel electrophoresis and using a 50 bp DNA marker as a reference.

\section{Statistical analysis}

The association strength between the target polymorphisms and IDD risk was measured by odds ratio (OR) with a $95 \%$ confidence interval $(\mathrm{Cl})$ using GraphPad-InStat 3.06 software. The distribution of genotype and allelic frequencies, the risk associated with individual genotype or allele with age, sex, BMI, and smoking distribution in the IDD patients and the control group were compared using $t$ and chi-square tests. $P$-value is regarded as significant if $\leq 0.05$.

Table II Demographic characteristics of subjects included in the study.

\begin{tabular}{|l|c|c|c|c|}
\hline \multirow{3}{*}{ Variable } & Status & $\begin{array}{c}\text { Patients } \\
(\mathrm{n}=155) \\
\mathrm{n}(\%)\end{array}$ & $\begin{array}{c}\text { Control } \\
(\mathrm{n}=55) \\
\mathrm{n}(\%)\end{array}$ & $P$ value \\
\hline \multirow{3}{*}{ Sex } & Male & $73(47.3)$ & $24(43.6)$ & 0.7532 \\
\cline { 2 - 5 } & Female & $82(52.7)$ & $31(56.4)$ & \\
\cline { 2 - 5 } & $30-40$ & $27(17.1)$ & $10(18.2)$ & \\
\cline { 2 - 5 } & $41-50$ & $47(30.3)$ & $22(40)$ & \\
\cline { 2 - 5 } & $51-60$ & $41(26.3)$ & $16(29.1)$ & \\
\hline Age range & $>60$ & $40(26.3)$ & $7(12.7)$ & \\
\hline Mean Age & & $30-77$ & $36-77$ & \\
\hline Smoking & Yes & $50(32)$ & $14(25)$ & 0.3966 \\
\hline \multirow{2}{*}{ BMI } & No & $105(68)$ & $41(75)$ & \\
\cline { 2 - 5 } & $19-25$ & $16(10.4)$ & $10(18.2)$ & \\
\cline { 2 - 5 } & $26-30$ & $56(36.4)$ & $39(70.9)$ & \\
\cline { 2 - 5 } & $>30$ & $83(53.2)$ & $6(10.9)$ & \\
\hline BMI-total & & 31 & 26.5 & $<0.005$ \\
\hline
\end{tabular}

Table I Forward and reverse primers for the target sequences.

\begin{tabular}{|c|c|c|c|c|}
\hline Genes & Rs \#. & Forward primers & Reverse primers & Ref \\
\hline IL-1 $\alpha$ & rs1800587 & 5'GCATGCCATCACACCTAGTT3' & 5'TTACATATGAGCCTTCCATG3' & $\begin{array}{c}\text { How } \\
\text { et al., 2007 }\end{array}$ \\
\hline IL-1 $\beta$ & rs1143634 & 5'CTCAGGTGTCCTCGAAGAAATCAA3' & 5'GCTTTTTTGCTGTGAGTCCCG3' & $\begin{array}{c}\text { Trevilatto } \\
\text { et al., 2011 }\end{array}$ \\
\hline VDR & rs731236 & 5'CAGAGCATGGACAGGGAGCAAG3' & 5'GCAACTCCTCATGGCTGAGGTCTCA3' & $\begin{array}{c}\text { Riggs } \\
\text { et al., 2009 }\end{array}$ \\
\hline VDR & rs2228570 & 5'AGCTGGCCCTGGCACTGACTCTGCTCT3' & 5'ATGGAAACACCTTGCTTCTTCTCCCTC3' & $\begin{array}{l}\text { Harris } \\
\text { et al., 1997 }\end{array}$ \\
\hline
\end{tabular}




\section{Results}

Patients with IDD and control subjects with a mean age of 52.6 versus 50.6 years, respectively, were included in the study. In the IDD group, 73 $(47.3 \%)$ were males compared to the $24(43.6 \%)$ males in the control group. BMI for the IDD and control groups were 31 and $26.5 \mathrm{~kg} / \mathrm{m}^{2}$, respectively. Therefore, the patients' group fell into the obese class I category while the control group fell into an overweight category, according to the World Health Organization (Table II). Representative gels for the determination of rs 1800587 of IL-1 $\alpha$ gene, rs 1143634 of IL-1 $\beta$ gene, and rs 2225870 and rs 731236 of VDR gene polymorphisms are shown in Figure 1. Rs 1800587 polymorphism of the IL-1 $\alpha$ gene showed no significant association with IDD disease (Table III). The distribution of T risk allele in patients and control was $56.1 \%$ versus $56.4 \%(p=$ $0.976 ; \mathrm{OR}=1.01 ; 95 \% \mathrm{Cl}: 0.5429$ to 1.877$)$, genotype frequencies between IDD and control groups were $43.9 \%$ versus $43.6 \%$ for CC; $14.8 \%$ ver-

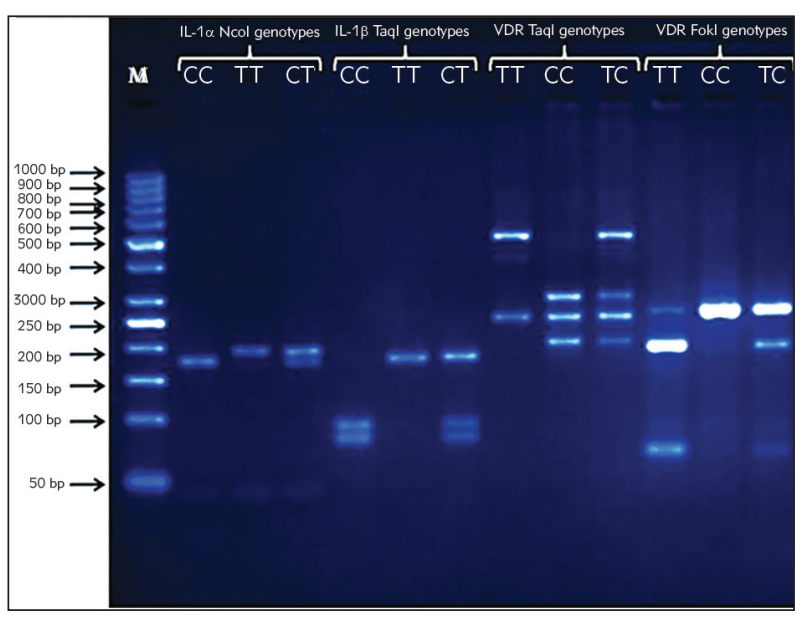

Figure 1 Representative gel for the determination of the polymorphisms rs 1800587, rs 1143634, rs 731236, and rs2228570, genotypes in twelve subjects are shown. In the first lane, there is a molecular weight DNA ladder $(M)$ for the size estimation of the DNA fragments.

Table III Genotypes and allelic frequencies of the polymorphisms rs1800587 of IL-1 $\alpha$ gene, rs 1143634 of IL-1 gene, and rs2228570 and rs731236 of VDR genes for patients and controls.

\begin{tabular}{|c|c|c|c|c|}
\hline & Genotype & Patients (\%) & Control (\%) & Statistical analysis \\
\hline \multirow{4}{*}{ rs1800587 (IL-1 $\alpha)$} & CC & $68(43.9)$ & $24(43.6)$ & $\left(\chi^{2}=0.181\right)(p=0.914)$ \\
\hline & TT & $23(14.8)$ & $7(12.7)$ & \\
\hline & CT & $64(41.3)$ & $24(43.6)$ & \\
\hline & T Allele frequency & $87(56.1)$ & $31(56.4)$ & $\begin{array}{c}(\mathrm{OR}=1.01) \\
(95 \% \mathrm{Cl}: 0.5429 \text { to } 1.877) \\
(p=0.976)\end{array}$ \\
\hline \multirow{4}{*}{ rs1143634 (IL-1ß) } & CC & $79(51)$ & $15(27.3)$ & $\left(\chi^{2}=19.253\right)$ \\
\hline & TT & $18(11.6)$ & $1(1.8)$ & $(p=<0.0001)$ \\
\hline & CT & $58(37.4)$ & $39(70.9)$ & \\
\hline & T Allele frequency & $76(49)$ & $40(72.7)$ & $\begin{array}{c}(\mathrm{OR}=2.772) \\
(95 \% \mathrm{Cl}: 1.416 \text { to } 5.428) \\
(\mathrm{p}=0.004)\end{array}$ \\
\hline \multirow{4}{*}{ rs2228570 (VDR) } & TT & $21(13.5)$ & $4(7.3)$ & $\left(\chi^{2}=1.651\right)(p=0.438)$ \\
\hline & $\mathrm{CC}$ & $75(48.4)$ & $30(54.5)$ & \\
\hline & TC & $59(38.1)$ & $21(38.2)$ & \\
\hline & C Allele frequency & $134(86.5)$ & $51(92.7)$ & $\begin{array}{c}\mathrm{OR}=1.998 \\
(95 \% \mathrm{Cl}: 0.6538 \text { to } 6.106) \\
(p=0.321)\end{array}$ \\
\hline \multirow{4}{*}{ rs731236 (VDR) } & TT & $48(31)$ & $18(32.7)$ & $\left(\chi^{2}=0.058\right)(p=0.971)$ \\
\hline & CC & $26(16.8)$ & $9(16.4)$ & \\
\hline & TC & $81(52.3)$ & $28(50.9)$ & \\
\hline & C Allele frequency & 107 (69) & $37(67.3)$ & $\begin{array}{c}\mathrm{OR}=0.922 \\
(95 \% \mathrm{Cl}: 0.4774 \text { to } 1.781) \\
(p=0.942)\end{array}$ \\
\hline
\end{tabular}


Table IV Genotypes and allelic frequencies of the polymorphisms rs 1800587 of IL-1 $\alpha$ gene, rs 1143634 of IL-1 gene, and rs2228570 and rs731236 of VDR genes in females for patients and controls.

\begin{tabular}{|c|c|c|c|c|}
\hline & Genotype & Patients (\%) & Control (\%) & Statistical analysis \\
\hline \multirow{4}{*}{$\begin{array}{l}\text { rs1800587 } \\
\quad(\mathrm{IL}-1 \alpha)\end{array}$} & $\mathrm{CC}$ & $35(42.7)$ & $13(41.9)$ & $\left(\chi^{2}=1.172\right)(p=0.557)$ \\
\hline & TT & $14(17.1)$ & $3(9.7)$ & \\
\hline & $\mathrm{CT}$ & $33(40.2)$ & $15(48.4)$ & \\
\hline & T Allele frequency & $47(57.3)$ & 18 (58.1) & $\begin{array}{c}(\mathrm{OR}=1.031) \\
(95 \% \mathrm{Cl}: 0.4464 \text { to } 2.381) \\
(p=0.943)\end{array}$ \\
\hline \multirow{4}{*}{$\begin{array}{c}\text { rs1143634 } \\
(I L-1 \beta)\end{array}$} & CC & $43(52.4)$ & $8(25.8)$ & $\left(\chi^{2}=11.712\right)(p=0.003)$ \\
\hline & TT & $10(12.2)$ & $1(3.2)$ & \\
\hline & CT & 29 (35.4) & $22(71)$ & \\
\hline & T Allele frequency & 39 (47.6) & $23(74.2)$ & $\begin{array}{c}(\mathrm{OR}=3.17) \\
(95 \% \mathrm{Cl}: 1.271 \text { to } 7.907) \\
(p=0.02)\end{array}$ \\
\hline \multirow{4}{*}{ rs2228570 (VDR) } & TT & $17(20.7)$ & $2(6.5)$ & $\left(\chi^{2}=5.36\right)(p=0.069)$ \\
\hline & CC & 28 (34. 1) & $17(54.8)$ & \\
\hline & $\mathrm{TC}$ & 37 (45.1) & $12(38.7)$ & \\
\hline & C Allele frequency & 65 (79.3) & 29 (93.5) & $\begin{array}{c}(\mathrm{OR}=3.792) \\
(95 \% \mathrm{Cl}: 0.8216 \text { to } 17.505) \\
(p=0.126)\end{array}$ \\
\hline \multirow{4}{*}{$\begin{array}{l}\text { rs731236 } \\
\text { (VDR) }\end{array}$} & TT & $26(31.7)$ & $8(25.8)$ & $\left(\chi^{2}=0.997\right)(p=0.607)$ \\
\hline & CC & $17(20.7)$ & $5(16.1)$ & \\
\hline & $\mathrm{TC}$ & $39(47.6)$ & $18(58.1)$ & \\
\hline & C Allele frequency & $56(68.3)$ & $23(74.2)$ & $\begin{array}{c}(\mathrm{OR}=1.335) \\
(95 \% \mathrm{Cl}: 0.5269 \text { to } 3.381) \\
(p=0.704)\end{array}$ \\
\hline
\end{tabular}

Table V Genotypes and allelic frequencies of the polymorphisms rs 1800587 of IL-1 $\alpha$ gene, rs 1143634 of IL-1 gene, and rs2228570 and rs731236 of VDR genes in males for patients and controls.

\begin{tabular}{|c|c|c|c|c|}
\hline Genotype & Patients (\%) & Control (\%) & Statistical analysis & \\
\hline \multirow{4}{*}{$\begin{array}{l}\text { rs1800587 } \\
\quad(\text { IL-1 } 1 \alpha)\end{array}$} & CC & $32(43.8)$ & $11(45.8)$ & $\left(\chi^{2}=0.441\right)(p=0.802)$ \\
\hline & TT & $9(12.3)$ & $4(16.7)$ & \\
\hline & CT & $32(43.8)$ & $9(37.5)$ & \\
\hline & T Allele frequency & $41(56.2)$ & $13(54.2)$ & $\begin{array}{c}(\mathrm{OR}=.922) \\
(95 \% \mathrm{Cl}: 0.3651 \text { to } 2.330) \\
(p=0.864)\end{array}$ \\
\hline \multirow{4}{*}{$\begin{array}{c}\text { rs1143634 } \\
\text { (IL-1 } \beta)\end{array}$} & CC & 36 (49.3) & $7(29.2)$ & $\left(\chi^{2}=7.252\right)(p=0.027)$ \\
\hline & TT & $7(9.6)$ & $0(0)$ & \\
\hline & $\mathrm{CT}$ & $30(41.1)$ & $17(70.8)$ & \\
\hline & T Allele frequency & $37(50.7)$ & $17(70.8)$ & $\begin{array}{c}(\mathrm{OR}=2.363) \\
(95 \% \mathrm{Cl}: 0.8755 \text { to } 6.377) \\
(p=0.137)\end{array}$ \\
\hline \multirow{4}{*}{$\begin{array}{c}\text { rs2228570 } \\
\text { (VDR) }\end{array}$} & TT & $7(9.6)$ & $2(8.3)$ & $\left(\chi^{2}=0.298\right)(p=0.862)$ \\
\hline & $\mathrm{CC}$ & $43(58.9)$ & $13(54.2)$ & \\
\hline & TC & $23(31.5)$ & $9(37.5)$ & \\
\hline & C Allele frequency & $6(90.4)$ & $22(91.7)$ & $\begin{array}{c}(\mathrm{OR}=1.167) \\
(95 \% \mathrm{Cl}: 0.2253 \text { to } 6.040) \\
(p=0.854)\end{array}$ \\
\hline \multirow{4}{*}{$\begin{array}{c}\text { rs731236 } \\
\text { (VDR) }\end{array}$} & TT & $20(27.4)$ & $10(41.7)$ & $\left(\chi^{2}=2.282\right)(p=0.320)$ \\
\hline & CC & $10(13.7)$ & $4(16.7)$ & \\
\hline & TC & $43(58.9)$ & $10(41.7)$ & \\
\hline & C Allele frequency & $53(72.6)$ & $14(58.3)$ & $\begin{array}{c}(\mathrm{OR}=0.528) \\
(95 \% \mathrm{Cl}: 0.2021 \text { to } 1.381) \\
(p=0.290)\end{array}$ \\
\hline
\end{tabular}


sus $12.7 \%$ for TT; and $41.3 \%$ versus $43.6 \%$ for CT, respectively $(p=0.914)$ (Table $I I I)$.

The genotype frequencies of rs 1143634 of the IL-1 $\beta$ gene were inversely associated with IDD. The frequency of $T$ allele was almost 1.5 folds higher in control group $(72.7 \%$ versus $49 \%, p=0.004, \mathrm{OR}=$ $2.772, \mathrm{Cl}: 1.416$ to 5.428$)$. Additionally, this was reflected in genotype frequencies observed in the control group - $51 \%$ versus $27.3 \%$ for CC; $11.6 \%$ versus $1.8 \%$ for $\mathrm{TT}$; and $37.4 \%$ versus $70.9 \%$ for $\mathrm{CT}$, respectively $(p<0.0001)$ (Table III). Additionally, frequencies of $\mathrm{T}$ allele in patients and control were $49 \%$ versus $72.7 \%(p=0.004 ;$ OR $=2.772 ; 95 \% \mathrm{Cl}$ : 1.416to 5.428). Therefore, our results demonstrated that the presence of rs 1143634 polymorphism of IL$1 \beta$ ( $\mathrm{T}$ allele) was higher in controls than in patients, indicating no association between this polymorphism and IDD; also, CC genotype was more frequent in patients in comparison to the control group (Table III).

Allelic frequencies of rs 2228570 polymorphism of the VDR gene in patients and controls were as the following: $C$ allele $86.5 \%$ in patients versus $92.7 \%$ in the control group ( $p=0.438 ; \mathrm{OR}=1.998 ; 95 \% \mathrm{Cl}$ : 0.6538 to 6.106$)$. Genotypes frequencies were $13.5 \%$ versus $7.3 \%$ for TT; $48.4 \%$ versus $54.5 \%$ for CC; and $38.1 \%$ versus $38.2 \%$ for TC, in patients and control group, respectively $(p=0.438)$ (Table $I I I)$. Our findings showed that the TT genotype was predominant in patients (1.998 fold higher) (Table III). For rs 731236 polymorphism of VDR gene, the genotypes frequencies among patients and controls were $31 \%$ versus $32.7 \%$ for TT; $16.8 \%$ versus $16.4 \%$ for CC; and $52.3 \%$ versus $50.9 \%$ for TC, respectively ( $p$ $=0.971$ ) (Table III). The distribution of $C$ allele was $69 \%$ versus $67.3 \%(p=0.942 ;$ OR $=0.922 ; 95 \%$ $\mathrm{Cl}: 0.4774$ to 1.781$)$, respectively. Thus there was no significant association between this polymorphism and IDD disease $(p>0.05)$ (Table III).

The analysis of the association among the studied polymorphisms and IDD according to sex revealed that there was no significant association between any of the polymorphisms and IDD (Tables IV and V).

\section{Discussion}

The genetic predisposition has been studied for its contribution to the degeneration process leading to an acceleration of ECM degradation or influencing inflammation and pain (2-4, 8, 9, 11-13, 17-19). Genes of interest include functional genes, such as IL1 gene and VDR, and structural genes, such as aggrecan and collagen. These sets of genes have been commonly studied due to their importance in normal mineralization and tissue remodelling (20$23)$. In this study, the association between the polymorphisms rs 1800587 of IL-1 $\alpha$, rs 1143634 of IL- $1 \beta$ and rs 2228570 and rs 731236 of VDR, and IDD has been investigated.
Previous studies suggested that $I L-1$ participates in IVD degeneration through suppression of ECM proteoglycans and collagen synthesis, increasing the production of ECM-degrading enzymes by stimulating proteases synthesis (24). Normally, IL-1 is expressed and regulated in the disc cells through a balance of activating and inhibiting receptors (IL-1RI and IL-1Ra, respectively), in the case of disc degeneration, this process becomes unbalanced (local overproduction of $I L-1 R I$ and/or underproduction of IL-1Ra) (20). The current study showed no significant association between rs 1800587 polymorphism of the IL-1 $\alpha$ gene and IDD development, and some convincing evidence exists in the literature. For instance, a previous case-control study of the Spanish population found no association between $\mathrm{T}$ allele and symptomatic lumbar disc herniation (21). Also, a study in the north-western Mexican Mestizo population showed that the distribution of $\mathrm{T}$ allele in patients and controls was $27.0 \%$ versus $28.0 \%$ ( $p=0.455)$, supporting the lack of association between rs 1800587 polymorphism and IDD (4). Moreover, Kelempisioti et al. (25) demonstrated the lack of any correlation between rs 1800587 polymorphism and IDD. Interestingly, a significant association of rs 1800587 polymorphism with the IDD in a Finnish population exhibiting the TT genotype of the $I L-1 \alpha$ gene as an increased risk factor of the disc bulges 3-folds compared to the CC genotype has been reported (26). Another study on 12 to 14-year-old Danish children also found an association between rs 1800587 polymorphism and disc degeneration in females (27). The inconsistent association between rs 1800587 polymorphism and IDD could be attributed to ethnic differences, where different haplotypes in the promoter or enhancer regions and/or environmental factors can explain the variations (4).

$I L-1 \beta$ has numerous pro-inflammatory properties that have been correlated with the pathogenesis of IDD (22). The current study demonstrated that the presence of rs 1143634 polymorphism of $I L-1 \beta$ (T allele) was higher in the control group than in the IDD group. This finding can be related to the fact that IDD can be asymptomatic (28). The control group in this study was chosen based on the absence of clinical symptoms only. However, an MRI scan, the gold standard for the diagnosis of IDD (29), could have revealed IDD in the control group, indicating the lack of association between this polymorphism and IDD. Videman et al. (10), in a study on 588 Finnish men, have shown that rs 1143634 polymorphism is not associated with IDD in MRI diagnosed patients. Also, Karppinen et al. (30) reported that in a Finnish male population, the rs 1143634 polymorphism was not correlated with Modic changes in vertebral endplates. In addition, a study by Kelempisioti et al. (25) on 538 Finnish young adults did not find any correlation between rs 1143634 polymorphism and IDD. On the other hand, several studies found an association 
between rs 1143634 polymorphism and IDD, for instance, in Finnish individuals, the $T$ allele of the rs 1143634 polymorphism of IL-1 gene is more frequent in patients with disc bulge $(26,31)$. These inconsistencies are explained by the interference of other genetic variations or environmental factors. Furthermore, Solovieva et al. (32), in 2006, reported an interaction between the rs 1143634 polymorphism and the Trp3 allele of the COL9A3 gene. They showed that the carriage of the Trp3 allele of COL9A3 in the absence of the T allele of IL-1 increased the risk of dark nucleus pulposus and joint occurrence of degenerative changes, while there was no effect of the Trp 3 allele in the presence of the IL$1 \mathrm{~T}$ allele, suggesting that IL-1 gene polymorphism may modify the effect of the COL9A3 in IDD patients (32).

Our results of rs 1800587 of IL- $1 \alpha$ and rs 1143634 of IL-1 polymorphisms, consistent with the findings of Noponen-Hietala et al. (16) did not find an association between rs 1800587 of IL- $1 \alpha$ and rs 1143634 of IL-1 polymorphisms and IDD. Therefore, other interleukin genes such as IL-1RN and their structural counterparts (e.g., Col9A3) should be taken into account, and their role in the IDD development investigated in this cohort.

The role of VDR gene polymorphism (rs2228570) was also examined in this cohort. Despite the high frequency of the TT genotype in the patients' group versus the control group. Our results did not show any significant association between rs2228570 and the presence of IDD. Likewise, Eskola, in 2012, found no association between rs2228570 polymorphism and IDD in young Danish females (31). Also, Serrano et al. (4), in 2014, showed that rs 2228570 polymorphism of the DR gene was not associated with IDD. On the contrary, other studies have shown an association between rs2228570 polymorphism and IDD (17). VDR is involved in bone and cartilage maintenance, such that alterations in the ECM function and the sulfation of glycosaminoglycans affect the disc and can cause degeneration. The first reported involvement of VDR variants in IDD was in the Finnish population (17), and later on, in other studies in Japanese and Chinese populations, the association was demonstrated (11, 12 ). On the other hand, many studies on genetically different populations have not found a relationship between VDR polymorphisms and IDD (31). Rs 2228570 polymorphism (ATG to ACG) of VDR gene occurs at the first of the two potential translation initiation site in exon 2 in the $5^{\prime}$ promoter region, individuals with the $T$ allele begin translation at the first initiation site generating a complete protein, while those with the $\mathrm{C}$ allele start translation at the second initiation site and generate a smaller protein. The shorter allele interacts efficiently with the transcriptional factor and displays a slight increase in function when compared to the longer one.
While rs 731236 polymorphism is a single base substitution T/C (ATT to ATC) causing a synonymous change (isoleucine) at codon 352 in exon 9 of the VDR gene close to the $3^{\prime}$ terminus, this polymorphism does not determine a structural modification in the receptor and is associated with the increased transcriptional activity, regulation of mRNA stability, and high serum level of 1,25-dihydroxy vitamin D3 (19). However, our findings demonstrated that rs 731236 polymorphism of the VDR gene was not associated with IDD, on the contrary, a report of the Finnish population, Videman et al. found that the signal intensities of thoracic and lumbar (T6-S1) discs were 12.9\% worse in men with the CC genotype and $4.5 \%$ worse in men with the TC genotype, compared with signal intensity in men with the TT genotype (17). An association between rs 731236 and rs 2228570 polymorphisms of the VDR gene and IDD was reported in other populations like Japanese, Chinese, and Turkish $(11,12,23)$.

Although the genetic basis of IDD is an area of current investigation that may define or lead to prevention or possible treatment options for disc degeneration, age-related and environmental factors which may synergistically culminate in disc degeneration should not be underestimated. This study has focused on obesity, where the mean BMl of the patient's group $\left(31.0 \mathrm{~kg} / \mathrm{m}^{2}\right)$ was significantly higher than that of the control group $\left(26.5 \mathrm{~kg} / \mathrm{m}^{2}\right)$. This increase in $\mathrm{BMI}$ among patients represents a proportional relationship between obesity and IDD, presumably as a result of increasing load on a vertebral disc $(33,34)$. Additionally, the peptide hormone, leptin, secreted primarily from adipose tissues and is a marker of obesity, is also secreted from cartilage tissue cells, including nucleus pulposus (NP) cells of intervertebral discs. Leptin is capable of inducing the abnormal proliferation of NP cells, which might be a possible mechanism underlying the impact of obesity in disc degeneration (35-37).

Although the genetics of IDD needs to be further investigated, and eventually a GWAS type of studies must be launched as well, we should not underrate the modifiable and unmodifiable environmental factors such as obesity, occupation, smoking and biochemical stress (inflammation and oxidative stress) all in conjunction with the normal process of degeneration.

\section{Conclusion}

This study demonstrated that polymorphisms of rs 1800587 of IL-1 $\alpha$, rs 1143634 of IL-1 $\beta$, and rs2228570 and rs731236 of VDR genes are not associated with IDD. Other factors, such as obesity, or gene-gene, gene-environment, or gene-age interactions, as illustrated by $\mathrm{BMI}$, could potentially play a role. Further studies are needed to elucidate the 
potential association of other candidate genes polymorphisms and IDD in the Jordanian population. Understanding the etiology underlying IDD may help suggest a possible approach to delay the onset of IDD or, at least, aid in predicting the risk of developing the disease.

\section{References}

1. Walker BF, Muller R, Grant WD. Low back pain in Australian adults: the economic burden. Asia Pac J Public Health 2003; 15(2): 79-87.

2. Zhao J, Yang M, Shao J, Bai Y, Li M. Association Between VDR Fokl Polymorphism and Intervertebral Disk Degeneration. Genomics Proteomics Bioinformatics 2015; 13(6): 371-6.

3. Guiot BH, Fessler RG. Molecular biology of degenerative disc disease. Neurosurgery 2000; 47(5): 1034-40.

4. Cervin Serrano SC, Gonzalez Villareal D, Aguilar-Medina $M$, et al. Genetic polymorphisms of interleukin-1 alpha and the vitamin d receptor in Mexican mestizo patients with intervertebral disc degeneration. Int J Genomics 2014; 2014: 302568 .

5. Patino MG, Neiders ME, Andreana S, Noble B, Cohen RE. Collagen: an overview. Implant Dentistry 2002; 11(3): 280-5.

6. Antoniou J, Steffen T, Nelson F, et al. The human lumbar intervertebral disc: evidence for changes in the biosynthesis and denaturation of the extracellular matrix with growth, maturation, ageing, and degeneration. J Clin lnvest 1996; 98(4): 996-1003.

7. Adams MA, Roughley PJ. What is intervertebral disc degeneration, and what causes it? Spine (Phila Pa 1976) 2006; 31(18): 2151-61.

8. Battie MC, Videman T, Parent E. Lumbar disc degeneration: epidemiology and genetic influences. Spine (Phila Pa 1976) 2004; 29(23): 2679-90.

9. Urban JP, Roberts S. Degeneration of the intervertebral disc. Arthritis Res Ther 2003; 5(3): 120-30.

10. Videman T, Saarela J, Kaprio J, et al. Associations of 25 structural, degradative, and inflammatory candidate genes with lumbar disc desiccation, bulging, and height narrowing. Arthritis Rheum 2009; 60(2): 470-81.

11. Cheung KM, Chan D, Karppinen J, et al. Association of the Taq I allele in vitamin D receptor with degenerative disc disease and disc bulge in a Chinese population. Spine (Phila Pa 1976) 2006; 31(10): 1143-8.

12. Kawaguchi $Y$, Kanamori $M$, Ishihara H, Ohmori $K$, Matsui $\mathrm{H}$, Kimura T. The association of lumbar disc disease with vitamin-D receptor gene polymorphism. J Bone Joint Surg Am 2002; 84-A(11): 2022-8.

13. Uitterlinden $A G$, Burger $H$, Huang $Q$, et al. Vitamin $D$ receptor genotype is associated with radiographic

Acknowledgements. This research was supported by the Deanship of Scientific Research and Graduate Studies at Yarmouk University, Grant \#20/2017.

\section{Conflict of interest statement}

The authors stated that they have no conflicts of interest regarding the publication of this article.

osteoarthritis at the knee. J Clin Invest 1997; 100(2): 259-63.

14. Avci E, Demir S, Aslan D, Nar R, Şenol H. Assessment of Abbott Architect 25-OH vitamin D assay in different levels of vitamin D. J Med Biochem, 2020; 39(1): 100-7.

15. Pociot F, Molvig J, Wogensen L, Worsaae H, Nerup J. A Taql polymorphism in the human interleukin-1 beta (IL-1 beta) gene correlates with IL-1 beta secretion in vitro. Eur J Clin Invest 1992; 22(6): 396-402.

16. Noponen-Hietala N, Virtanen I, Karttunen R, et al. Genetic variations in IL6 associate with intervertebral disc disease characterized by sciatica. Pain 2005; 114(1-2): 186-94.

17. Videman T, Leppavuori J, Kaprio J, et al. Intragenic polymorphisms of the vitamin $D$ receptor gene associated with intervertebral disc degeneration. Spine (Phila Pa 1976) 1998; 23(23): 2477-85.

18. Uitterlinden $A G$, Fang $Y$, Bergink AP, van Meurs JB, van Leeuwen HP, Pols HA. The role of vitamin $D$ receptor gene polymorphisms in bone biology. Mol Cell Endocrinol 2002; 197(1-2):15-21.

19. Morrison NA, Qi JC, Tokita A, et al. Prediction of bone density from vitamin D receptor alleles. Nature 1994; 367(6460): 284-7.

20. Le Maitre CL, Freemont AJ, Hoyland JA. The role of interleukin-1 in the pathogenesis of human intervertebral disc degeneration. Arthritis Res Ther 2005; 7(4): R732-45.

21. Paz Aparicio J, Fernandez Bances I, Lopez-Anglada Fernandez E, et al. The IL-1beta (+3953 T/C) gene polymorphism associates to symptomatic lumbar disc herniation. Eur Spine J 2011; 20 Suppl 3: 383-9.

22. Wang Z, Qu Z, Fu C, et al. Interleukin 1 Polymorphisms Contribute to Intervertebral Disc Degeneration Risk: A Meta-Analysis. PLoS One 2016; 11(6): e0156412.

23. Eser B, Cora T, Eser O, et al. Association of the polymorphisms of vitamin $D$ receptor and aggrecan genes with degenerative disc disease. Genet Test Mol Biomarkers 2010; 14(3): 313-7.

24. Kepler CK, Ponnappan RK, Tannoury CA, Risbud MV, Anderson DG. The molecular basis of intervertebral disc degeneration. Spine J 2013; 13(3): 318-30.

25. Kelempisioti A, Eskola PJ, Okuloff A, et al. Genetic susceptibility of intervertebral disc degeneration among young Finnish adults. BMC Med Genet 2011; 12: 153. 
26. Solovieva $S$, Kouhia $S$, Leino-Arjas $P$, et al. Interleukin 1 polymorphisms and intervertebral disc degeneration. Epidemiology 2004; 15(5): 626-33.

27. Eskola PJ, Kjaer P, Daavittila IM, et al. Genetic risk factors of disc degeneration among 12-14-year-old Danish children: a population study. Int J Mol Epidemiol Genet 2010; 1(2): 158-65.

28. Brinjikji W, Luetmer PH, Comstock B, et al. Systematic literature review of imaging features of spinal degeneration in asymptomatic populations. American Journal of Neuroradiology 2015; 36(4): 811-6.

29. Wang C, McArdle E, Fenty M, et al. Validation of Sodium MRI of Intervertebral Disc. Spine 2010; 35(5): 505.

30. Karppinen J, Solovieva S, Luoma K, Raininko R, LeinoArjas $\mathrm{P}$, Riihimaki $\mathrm{H}$. Modic changes and interleukin 1 gene locus polymorphisms in occupational cohort of middle-aged men. Eur Spine J 2009; 18(12): 1963-70.

31. Eskola PJ, Lemmela S, Kjaer P, et al. Genetic association studies in lumbar disc degeneration: a systematic review. PLoS One 2012; 7(11): e49995.

32. Solovieva S, Lohiniva J, Leino-Arjas $P$, et al. Intervertebral disc degeneration in relation to the COL9A3 and the IL-1ss gene polymorphisms. Eur Spine J 2006; 15(5): 613-9.

33. Samartzis D, Karppinen J, Chan D, Luk KD, Cheung KM. The association of lumbar intervertebral disc degeneration on magnetic resonance imaging with body mass index in overweight and obese adults: a population based study. Arthritis \& Rheumatism 2012; 64(5): 1488-96.

34. Hangai M, Kaneoka K, Kuno S, et al. Factors associated with lumbar intervertebral disc degeneration in the elderly. The Spine Journal 2008; 8(5): 732-40.

35. Li Z, Shen J, Wu WKK, et al. Leptin induces cyclin D1 expression and proliferation of human nucleus pulposus cells via JAK/STAT, PI3K/Akt and MEK/ERK pathways. PloS one 2012; 7(12): e53176.

36. Segar AH, Fairbank JC, Urban J. Leptin and the intervertebral disc: A biochemical link exists between obesity, intervertebral disc degeneration and low back pain-an in vitro study in a bovine model. European Spine Journal 2019; 28(2): 214-23.

37. Zhao C-Q, Liu D, Li H, Jiang L-S, Dai L-Y. Expression of Leptin and its functional receptor on disc cells: contribution to cell proliferation. Spine 2008; 33(23): E858E64. 